\title{
Age, sex, and affected side distribution of concha bullosa subtypes
}

\section{Konka bülloza alt tiplerinin yaş, cinsiyet ve görüldü̈̆̈̈ tarafa göre dă̆glımı}

\author{
Elif Elibol ${ }^{1}\left[\right.$, Hacer Baran² ${ }^{(10}$ \\ ${ }^{1}$ Department of Otolaryngology, Ankara Yildırm Beyazıt University, Yenimahalle Training and Research Hospital, Ankara, Turkey \\ ${ }^{2}$ Department of Otolaryngology, Kartal Dr. Lütfi Kırdar Training and Research Hospital, Istanbul, Turkey
}

\section{ABSTRACT}

Objectives: This study aims to investigate the incidence of concha bullosa (CB) subtypes according to age, sex, and the affected side.

Patients and Methods: Paranasal sinus computed tomography (PNS CT) scans of a total of 300 patients (157 males, 143 females; mean age $34 \pm 6.4$ years; range, 18 to 60 years) with CB between January 2019 and January 2020 were retrospectively analyzed. The subtypes of $\mathrm{CB}$ were determined and the relationship between chronic sinusitis findings, sex, and age sociodemographic features, and the affected side was evaluated.

Results: The incidence of $\mathrm{CB}$ subtypes did not change according to age $(p>0.05)$, while the incidence of extensive and lamellar $\mathrm{CB}$ was significantly higher in females than males $(p<0.05)$. Lamellar and extensive CB were significantly higher in the right side than the left side $(\mathrm{p}<0.05)$. Extensive $\mathrm{CB}$ was observed more bilaterally than other concha subtypes.

Conclusion: Concha bullosa subtypes and their incidences may vary according to sex, age, and side on which they are seen.

Keywords: Anatomic variation, computed tomography, nasal concha, paranasal sinus.

Concha bullosa (CB) is a common sinonasal anatomic variation mostly seen in the middle concha which can be also observed in the lower and upper conchas, even in all three conchas at the same time and which can be unilateral or bilateral. ${ }^{[1]}$ It is usually asymptomatic, can be often diagnosed incidentally
$\ddot{O} Z$

Amaç: Bu çalışmada konka büllloza (KB) alt tiplerinin yaş, cinsiyet ve görüldüğü tarafa göre görülme sıklıkları araştırıld..

Hastalar ve Yöntemler: Ocak 2019 - Ocak 2020 tarihleri arasında $300 \mathrm{~KB}$ hastasının (157 erkek, 143 kadın; ort. yaş $34 \pm 6.4$ yıl; dağılım 18-60 yıl) paranazal sinüs bilgisayarlı tomografi (PNS BT) taraması retrospektif olarak incelendi. Konka büllozanın alt tipleri belirlendi ve kronik sinüzit bulguları, cinsiyet ve sosyodemografik yaş özellikleri ve etkilenen alan arasındaki ilişki değerlendirildi.

Bulgular: Yaşa göre $\mathrm{KB}$ alt tiplerinde görülme sıklığ değişmezken ( $p>0.05)$, ekstensif ve lamellar KB görülme sıklığ erkeklere kıyasla kadınlarda anlamlı olarak daha yüksek idi $(\mathrm{p}<0.05)$. Sol tarafa kıyasla, sağ tarafta lamellar ve ekstensif $\mathrm{KB}$ anlamlı olarak daha fazla idi $(\mathrm{p}<0.05)$. Ekstensif $\mathrm{KB}$, diğer konka alt tiplerine kıyasla, daha fazla iki taraflı olarak izlendi $(\mathrm{p}<0.05)$.

Sonuç: Konka bülloza alt tipleri ve görülme sıklığı cinsiyete, yaşa ve görüldüğü tarafa göre değişiklik gösterebilir.

Anahtar sözcükler: Anatomik varyasyon, bilgisayarlı tomografi, nazal konka, paranasal sinüs.

by paranasal sinus tomography; however, it may also obstruct the ostiomeatal complex, causing sinusitis, headache, and nasal obstruction. ${ }^{[2]}$

It is known that this anatomic variation may obstruct the ostiomeatal complex and cause sinusitis by disrupting sinus ventilation with negative mucociliary

Received: June 06, 2020 Accepted: September 08, 2020 Published online: October 05, 2020

Correspondence: Elif Elibol, MD. Yıldırım Beyazıt Üniversitesi Yenimahalle Eğitim ve Araştırma Hastanesi Kulak Burun Boğaz Kliniği, 06370 Yenimahalle, Ankara, Türkiye. e-mail: delifzer@yahoo.com 
activity in the sinuses. It can often cause chronic sinusitis by causing aeration and mucociliary activity impairment with pressure and obstructive effect on surrounding structures. Stammberger has two different hypotheses about the effect of septal deviation in the formation of $\mathrm{CB} \cdot{ }^{[1]}$ The first is the "ex vacuo" theory in which septal deviation plays an important role. The other is the theory which argues that two different situations coincide by chance. Also, it is known that septum deviation can pressure the $\mathrm{CB}$ on the opposite side to grow. ${ }^{[3]}$

There are three subtypes of $\mathrm{CB}$. The type in which the vertical lamellar portion of the concha is aerated is called lamellar, while the type in which the lower part is aerated is called bulbous and the type in which both parts are aerated is called extensible CB. ${ }^{[4]}$

In this study, we aimed to investigate the relationship between $\mathrm{CB}$ subtypes, whether its presence of unilateral or bilateral, and the association between right or left as most commonly observed side, the sociodemographic patient characteristics such as age and sex, and incidence of the disease.

\section{PATIENTS AND METHODS}

This retrospective study was conducted at Ankara Yildırım Beyazıt University, Yenimahalle Training and Research Hospital between January 2019 and January 2020. Patients who applied with headache, facial pain, facial congestion, nasal congestion, lack of nasal breathing, inability to smell and odor, or postnasal discharge and underwent paranasal sinus computed tomography (PNS CT) were included in the study. The results and medical files of a total of 441 patients were evaluated retrospectively. Patients older than 18 years old, who did not previously have sinonasal surgery, and without sinonasal congenital anomalies were included. The PNS CTs of the patients with missing files and younger than 18 years old, with previous sinonasal surgeries or anomalies were excluded. Finally, a total of 300 patients (157 males, 143 females; mean age $34 \pm 6.4$ years; range, 18 to 60 years) were included in the study. Coronal sections of the PNS CT of the coronal plane (GE bright speed 16 section, Chicago, IL, USA) with $0.65-\mathrm{mm}$ sections were examined. A written informed consent was obtained from each patient. The study protocol was approved by the Ankara Yildirim Beyazit University, Yenimahalle Training and Research Hospital Ethics Committee. The study was conducted in accordance with the principles of the Declaration of Helsinki.

Concha bullosa was detected and subtypes were examined without measuring the pneumatization amount of the middle concha (Figure 1). Whether $\mathrm{CB}$ was unilateral or bilateral and the affected side were noted.

\section{Statistical analysis}

Statistical analysis was performed using the SPSS for Windows version 14.0 software (SPSS Inc., Chicago, IL, USA). Descriptive data were expressed in mean \pm standard deviation (SD), median (min-max) or number and frequency. The chi-square test was calculated for the reliability of the sub-dimensions. A $p$ value of $<0.05$ was considered statistically significant with $95 \%$ confidence interval (CI).

\section{RESULTS}

A total of $25.5 \%$ of the patients were in the age group of 18 to 30 years (Group 1), 26.1\% of them in the 30 to 40 age group (Group 2), 26.1\% of them in the 40 to 50 age group (Group 3), and $28.3 \%$ of them in the 50 to 60 age group (Group 4). There was no statistically significant difference in the incidence of lamellar, bulbous or extensible concha types among the groups according to age groups ( $>0.05)$, (Table 1$)$.
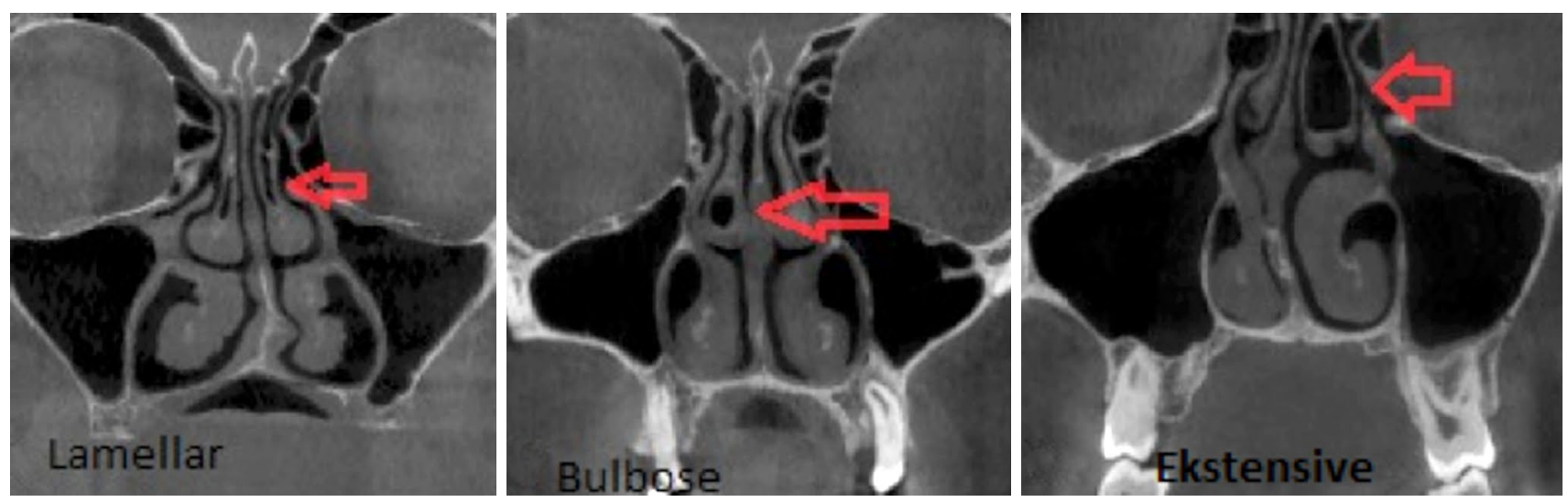

Figure 1. Computed tomography scans of subtypes of concha bullosa. 


\begin{tabular}{|c|c|c|c|c|c|c|c|c|c|c|c|c|c|c|}
\hline \multicolumn{15}{|c|}{$\begin{array}{c}\text { Table } 1 \\
\end{array}$} \\
\hline & \multirow{2}{*}{$\begin{array}{c}\text { Total } \\
\mathrm{n}\end{array}$} & \multicolumn{3}{|c|}{ Group 1} & \multicolumn{3}{|c|}{ Group 2} & \multicolumn{3}{|c|}{ Group 3} & \multicolumn{3}{|c|}{ Group 4} & \multirow[b]{2}{*}{$p$} \\
\hline & & $\mathrm{n}$ & $\%$ & $\begin{array}{c}\text { Age } \\
\text { (year) }\end{array}$ & $\mathrm{n}$ & $\%$ & $\begin{array}{l}\text { Age } \\
\text { (year) }\end{array}$ & $\mathrm{n}$ & $\%$ & $\begin{array}{c}\text { Age } \\
\text { (year) }\end{array}$ & $\mathrm{n}$ & $\%$ & $\begin{array}{c}\text { Age } \\
\text { (year) }\end{array}$ & \\
\hline Extensive & 70 & 18 & 25.7 & \multirow{4}{*}{$18-30$} & 21 & 30 & \multirow{4}{*}{$30-40$} & 19 & 27.1 & \multirow{4}{*}{$40-50$} & 22 & 31.4 & \multirow{4}{*}{$50-60$} & 0.983 \\
\hline Bulbous & 28 & 7 & 25 & & 6 & 21.4 & & 7 & 25 & & 8 & 28.2 & & 0.831 \\
\hline Lamellar & 51 & 13 & 25.4 & & 12 & 19.6 & & 13 & 25.4 & & 13 & 25.4 & & 0.949 \\
\hline Total & 149 & 38 & 25.5 & & 39 & 26.1 & & 39 & 26.1 & & 43 & 28.3 & & 0.845 \\
\hline
\end{tabular}

\begin{tabular}{|c|c|c|c|c|c|c|}
\hline \multicolumn{7}{|c|}{$\begin{array}{c}\text { Table } 2 \\
\text { Incidence of concha bullosa subtypes in different sex and side of computed tomography scans }\end{array}$} \\
\hline & \multicolumn{2}{|c|}{ Extensive } & \multicolumn{2}{|c|}{ Bulbous } & \multicolumn{2}{|c|}{ Lamellar } \\
\hline & $\mathrm{n}$ & $\%$ & $\mathrm{n}$ & $\%$ & $\mathrm{n}$ & $\%$ \\
\hline Right female & 24 & 8 & 9 & 3 & 18 & 6 \\
\hline Left female & 17 & 5.6 & 9 & 3 & 15 & 5 \\
\hline Right male & 16 & 5.3 & 5 & 1.6 & 10 & 3.3 \\
\hline Left male & 13 & 4.3 & 5 & 1.6 & 8 & 2.6 \\
\hline Total & 70 & 23.3 & 28 & 9.3 & 51 & 17 \\
\hline
\end{tabular}

The incidence of lamellar type $\mathrm{CB}$ was found to be different according to sex. It was observed in 7\% of males and $11 \%$ of females $(p=0.19)$. The incidence of extensive type $\mathrm{CB}$ showed a significant difference according to sex. It was observed in $9.6 \%$ of males and $13.6 \%$ of females $(p=0.24)$. There was no significant difference in the incidence of the bulbous $\mathrm{CB}$ subtypes according to sex ( $>0.05)$ (Table 2).

A statistically significant difference was observed for the incidence of lamellar $\mathrm{CB}$ in the right and left nose $(9.3 \%$ in the right nose and $7.6 \%$ in the left nose; $\mathrm{p}=037$ ). A statistically significant difference was observed for the incidence of extensive type $\mathrm{CB}$ in the right and left nose $(13.3 \%$ in the right nose and $9.6 \%$ in the left nose, $\mathrm{p}=028)$.

Bulbous type $\mathrm{CB}$ was observed in $4.6 \%$ of the right nose and $4.6 \%$ of the left nose. Since there was an insignificant difference in the number between the right and left side, it was shown in percentage. A total of 46 bilateral CB cases were bilateral. Of these, $27 \%(n=10)$ were found to be lamellar type, $8.3 \%(n=3)$ were the bulbous type, and $63.9 \%(n=23)$ were the extensive type.

We found a correlation between sex and side in both lamellar and extensive CB subtypes. Both lamellar and extensive types were seen commonly in females than males. Also, the incidence of both lamellar and extensive $\mathrm{CB}$ on the right side was higher than the left side. The most common bilaterally seen subtype of $\mathrm{CB}$ was found to be extensive. There was no significant correlation between age and $\mathrm{CB}$ subtypes.

\section{DISCUSSION}

With the introduction of functional endoscopic sinus surgery and renewed technological endoscopic systems, anatomical variations in the sinonasal region have gained more importance. The anatomical variations should be revealed better radiologically to determine the interventions to these regions and to understand the causes of sinonasal problems. There are several studies on this subject in the literature. The incidence of $\mathrm{CB}$ in the middle concha varies between 14 and 53.6\%. ${ }^{[5]}$ Aramani et al. ${ }^{[5]}$ found the incidence of $\mathrm{CB}$ to be $53.7 \%$, similar to Koo et al. ${ }^{[6]}$ The incidence of CB was $34.3 \%(n=103)$ in this study. While $45 \%$ of women had $\mathrm{CB}, 26 \%$ of men had $\mathrm{CB}$, indicating a significant difference in the incidence of $\mathrm{CB}$ among women and men $(p=0.128)$. In the previous studies, the sociodemographic incidence of $\mathrm{CB}$ was not included much in a more detailed way as being divided into subtypes, depending on whether the variation subtype was bilateral or unilateral, on the right or left. In this study, unlike other studies, the distribution of subtypes was given in detail and an additional contribution was made to the literature. To determine the incidence of $\mathrm{CB}$ subtypes by age, age groups were created in four 
groups and no significant difference was found among these four groups. As the incidence of all CB subtypes according to age did not change numerically according to the groups and the mean value was found to be the same in each decade; however, no correlation was found with age. In a prospective study, Kalaiarasi et a1., ${ }^{[7]}$ reported more information about the clinical findings and treatment results of $\mathrm{CB}$. However, in our study, clinical findings or possible treatment modalities were not investigated, since the study was specifically about to analyze the differentiation of the frequency of $\mathrm{CB}$ subtypes according to sex, age, and affected side using CT scans. The results of Kalaiarasi et al.'s ${ }^{[7]}$ study, the number of extensive, bullous and lamellar conchas were 49 (49.5\%), 28 (28.3\%), and $22(22.2 \%)$, respectively, consistent with the study by Tonai et al. ${ }^{[8]}$ In this study, the incidences of extensive, bulbous, and lamellar conchas were 70 (23.3\%), $28(9.3 \%)$, and 51 (17\%) without sex evaluation. Unlike other studies in the literature, when the sex was examined separately, bulbous and lamellar type CBs were found to be significantly higher in females than males, although there was no significant difference between both sexes in terms of the incidence of bulbous $\mathrm{CB}$. In a study conducted by Bolger et al. ${ }^{[9]}$ in which they examined PNS CT scans of 207 patients, the $\mathrm{CB}$ prevalence was found to be $51.7 \%$ in both nasal cavities, $26.7 \%$ in the right nasal cavity, and $21.7 \%$ in the left nasal cavity. The incidence of CB in this study was $22 \%(n=66)$ for the left nose and $27.6 \%(n=83)$ for the right nose. When the right and left incidence rates of $\mathrm{CB}$ subtypes were calculated, lamellar and extensive types of $\mathrm{CB}$ variations were significantly higher on the right. In a retrospective study using PNS CT scans by Devaraja et al., ${ }^{[10]} \mathrm{CB}$ was observed in $49 \%$ of 151 patients and bilateral in $40 \%$ of these patients. In this study, CB was bilateral in $15.3 \%(n=46)$ of the patients. The highest incidence of bilateral occurrence was seen in the extensive type $\mathrm{CB}$.

The main consideration in the introduction to sinus surgery is the ostiomeatal complex, which includes the uncinate process, ethmoid bulla, and hiatus semilunaris. Studies in the prior literature have shown that $\mathrm{CB}$ disrupts mucociliary transport by obstructing the ostiomeatal complex entrance. Therefore, for the CT scans of $\mathrm{CB}$ and subtypes taken, when the patient is admitted with sinusitis, headache or nasal obstruction complaints, although both sexes should be taken seriously, more attention should be paid to women. Radiological investigation of $\mathrm{CB}$ and subtypes would help the surgeon to identify the treatment steps and prevent any unforeseen complications during surgery. Total surgical resection, lateral/medial laminectomy, conchaplasty and turbinoplasty are used in the surgical treatment of CB. ${ }^{[11]}$

The retrospective design of this study is the main limitation. In addition, PNS CT findings were unable to be confirmed using endoscopy. The surgical procedures and success rates for the anatomic variations were unable to be evaluated, either.

In conclusion, there is a wide range of incidence and prevalence regarding sinonasal anatomic variations in the literature. These alterations depend on the type of study, measurement criteria of the assessor, and sociodemographic characteristics of the patient group. Our study results suggest that $\mathrm{CB}$ subtypes and their incidences may vary according to sex, age, and side on which they are seen.

\section{Declaration of conflicting interests}

The authors declared no conflicts of interest with respect to the authorship and/or publication of this article.

\section{Funding}

The authors received no financial support for the research and/or authorship of this article.

\section{REFERENCES}

1. Muñoz-Leija MA, Yamamoto-Ramos M, Barrera-Flores FJ, Treviño-González JL, Quiroga-Garza A, MéndezSáenz MA, et al. Anatomical variations of the ethmoidal roof: differences between men and women. Eur Arch Otorhinolaryngol 2018;275:1831-6.

2. Muhlis B, Güler B, İlhan T. Konka bülloza tipleri ve farklı patolojik içerik görülme sıklığı. Electronic Journal of Otolaryngology 2011;10:57-61.

3. Karki S, Pokharel M, Suwal S, Poudel R . Prevalence of Anatomical Variations of the Sinonasal Region and their Relationship with Chronic Rhinosinusitis. Kathmandu Univ Med J (KUMJ) 2016;14:342-6.

4. Kaya M, Çankal F, Gumusok M, Apaydin N, Tekdemir I. Role of anatomic variations of paranasal sinuses on the prevalence of sinusitis: Computed tomography findings of 350 patients. Niger J Clin Pract 2017;20:1481-8.

5. Aramani A, Karadi RN, Kumar S. A Study of Anatomical Variations of Osteomeatal Complex in Chronic Rhinosinusitis Patients-CT Findings. J Clin Diagn Res 2014;8:KC01-4.

6. Koo SK, Kim JD, Moon JS, Jung SH, Lee SH. The incidence of concha bullosa, unusual anatomic variation and its relationship to nasal septal deviation: A retrospective radiologic study. Auris Nasus Larynx 2017;44:561-70.

7. Kalaiarasi R, Ramakrishnan V, Poyyamoli S. Anatomical variations of the middle turbinate concha bullosa and its relationship with chronic sinusitis: A prospective radiologic study. Int Arch Otorhinolaryngol 2018;22:297-302. 
8. Tonai A, Baba S. Anatomic variations of the bone in sinonasal CT. Acta Otolaryngol Suppl 1996;525:9-13.

9. Bolger WE, Butzin CA, Parsons DS. Paranasal sinus bony anatomic variations and mucosal abnormalities: CT analysis for endoscopic sinus surgery. Laryngoscope 1991;101:56-64.
10. Devaraja K, Doreswamy SM, Pujary K, Ramaswamy B, Pillai S. Anatomical variations of the nose and paranasal sinuses: A computed tomographic study. Indian J Otolaryngol Head Neck Surg 2019;71(Suppl 3):2231-40.

11. Erkuş S, Kaya T, Turan T. Konka bulloza (Pnömatize Orta Konka). Türk Otolaryngoloji Arşivi 1992;30:220-4. 